\title{
Cooking Class Berbasis Kearifan Lokal Meningkatkan Motorik Halus Anak di Daerah Miskin
}

\author{
Khusnul Laely', Subiyanto ${ }^{2}$ \\ Pendidkan Guru Pendidikan Anak Usia Dini, Universitas Muhammadiyah Magelang1 \\ Bimbingan Konseling, Universitas Muhammadiyah Magelang2 \\ DOI: $\underline{10.31004 / \text { obsesi.v4i2.466 }}$
}

\begin{abstract}
Abstrak
Tujuan dalam penelitian ini untuk mengetahui model pembelajaran cooking class dalam meningkatkan motorik halus anak usia dini, menguji efektifitas pembelajaran cooking class untuk meningkatkan motorik halus anak, serta faktor-faktor yang mempengaruhi perkembangan motorik halus anak usia dini. Metode penelitian yang digunakan yaitu metode Penelitian Tindakan Kelas (PTK) pada POS PAUD Ar-Rayyan yang meliputi perencanaan penelitian, pelaksanaan penelitian, pengamatan dan refleksi penelitian. Hasil penelitian menunjukkan implementasi cooking class berbasis kearifan lokal mampu meningkatkan kemampuan motorik halus anak. Selain itu faktor yang mempengaruhi perkembangan motorik halus anak usia 3-4 tahun yaitu diantaranya stimulus yang diberikan oleh orang tua dan pendidik, kemandirian anak dalam kegiatan pembelajaran, kesadaran orang tua akan pentingnya proses daripada hasil, kepercayaan orang tua terhadap kemampuan anak, dan kedekatan emosional antara pendidik dan peserta didik.
\end{abstract}

Kata Kunci : motorik halus; cooking class; kearifan local; daerah miskin.

\begin{abstract}
The aim to be achieved in this research is the formation of cooking class learning models that can improve fine motor age of early childhood and can be implemented by PAUD teachers in daily learning, test the effectiveness of cooking class learning to improve children's fine motor skills, as well as influencing factors fine motor development of early childhood. The method used in this study is the Classroom Action Research (CAR) in POS PAUD Ar-Rayyan which includes research planning, conducting research, observing and reflecting research. The results showed the effectiveness of the implementation of cooking class based on local wisdom in stimulating children's fine motor skills, namely increasing fine motor skills from the initial data of $51.56 \%$, the first cycle of action increased to $62.67 \%$ and the second cycle to $79.11 \%$. In addition, several factors influence the development of fine motoric children aged 3-4 years, including stimuli given by parents and educators, independence of children in learning activities, awareness of parents about the importance of the process rather than results, parental trust in children's abilities, and closeness emotional between educators and students.
\end{abstract}

Keywords: fine motoric; cooking class based on local wisdom; poor areas.

Copyright (c) 2020 Sjafiatul Mardliyah, Hotman Siahaan, Tuti Budirahayu

$\triangle$ Corresponding author:

Email Address : sjafiatul.mardliyah.os-2015@fisip.unair.ac.id (Graha Sunan Ampel Wiyung Surabaya) Received 23 February 2020, Accepted 2 March 2020, Published 6 March 2020 


\section{PENDAHULUAN}

Penelitian ini dilaksanakan sebagai tindak lanjut dari Pengabdian multi year yang dibiayai oleh DRPM yang telah diperoleh oleh peneliti pada tahun 2016-2018 berjudul IbW Kabupaten Magelang: Mewujudkan Pusat Kegiatan Belajar Masyarakat (PKBM) Berbasis Kearifan lokal di Daerah Miskin.

PKBM yang telah dirintis bernama PKBM Omah Sinau. PKBM ini memiliki 4 program yaitu pendidikan, kesehatan, pengentasan kemiskinan, dan pertanian. Di bidang pendidikan telah dirintis Pos PAUD Ar-Rayyan. Pos PAUD dirintis dalam rangka meningkatkan kualitas sumber daya manusia. kualitas sumber daya manusia adalah salah satu tujuan pembangunan pendidikan yang ditetapkan oleh Pemerintah. Pemerintah Indonesia melalui Rencana Pembangunan Pendidikan Nasional Jangka Panjang (RPPNJP) 2005-2025 berupaya untuk memajukan pendidikan, saat ini pembangunan pendidikan direncanakan sebagai tahap pendidikan yang menyiapkan manusia Indonesia untuk memiliki daya saing regional (Pendidikan \& Kebudayaan, n.d.).

Pendidikan anak usia dini (PAUD) atau early childhood education (ECE) adalah pendekatan pedagogis dalam penyelenggaraan pendidikan anak yang dimulai dari 0 sampai 6 tahun (Santi, 2009). Berdasarkan tinjauan aspek pedagogis, masa usia dini merupakan pasa peletak dasar atau pondasi awal bagi pertumbuhan dan perkembangan selanjutnya (Nurani, 2009). Masa ini juga biasa disebut golden age dimana usia paling peka terhadap berbagai rangsangan. Ada 6 aspek yang harus dikembangkan oleh anak usia dini, satu diantaranya yaitu kemempuan motorik halus. Keadaan dimana anak mampu melakukan gerakan melalui penggunaan otot-otot kecil atau anggota tubuh tetentu dengan kecermatan dan koordinasi yang baik seperti keterampilan menggunakan tangan.

Pada dasarnya setiap anak memiliki kemampuan motorik baik motorik halus maupun motorik kasar yang berbeda antara anak yang satu dengan yang lainnya. Hal ini dikarenakan ada beberapa faktor yang mempengaruhi diantaranya faktor internal dan faktor eksternal. Faktor internal terdiri dari minat anak, gen, sedangkan faktor eksternal yaitu lingkungan belajar, pendidikan orang tua, dan lokasi anak tinggal. Hal ini sejalan dengan penelitian yang dilakukan pada anak usia 3-4 tahun dimana pendapatan yang didapatkan keluarga tidak akana berpengaruh dengan motorik anak, namun pendidikan keluarga memiliki pengaruh terhadap kemampuan motorik anak (Kusumaningtyas \& Wayanti, 2016). Pendidikan keluarga berhubungan dengan pengasuhan orang tua dalam memberikan stimulasi untuk mengembangkan kemampuan motorik anak usia dini. Perkembangan motorik halus dan motorik kasar yang dimiliki oleh masing-masing individu akan mempengaruhi kreatifitas anak (Romlah, 2017).

Kemampuan motorik halus anak pada dasarnya dapat distimulasi dengan berbagai kegiatan dalam pembelajaran. Kemampuan motorik halus anak dapat dikembangkan dengan mengimplementasikan kegiatan menganyam dalam proses pembelajaran di TK tepatnya di kelompok B (Ningrum, 2015). Melalui kegiatan menganyam, anak akan berusaha membuat hasil karya anyaman yang indah dengan menggunakan kemampuan kognitif dan tangan anak, sehingga secara tidak langsung motorik anak akan terlatih. Selain kegiatan menganyam, motorik halus anak juga dapat distimulasi dengan kegiatan mozaik. Kegiatan mozaik digunakan untuk meningkatkan perkembangan motorik halus anak dikarenakan sesuai dengan prinsip bermain (Indraswari, 2014). Origami juga mampu memotivasi anak dalam meningkatkan kemampuan motorik halus (Cllaudia, Wdiastuti, \& Kurniawan, 2018). Selain itu kegiatan kirigami juga berpengaruh terhadap kemampuan motorik halus anak (Rakimahwati, Lestari, \& Hartati, 2018). Hal ini sesuai dengan usia anak yaitu usia bermain, dimana segala sesuatu yang dilakukan anak dengan bermain. Melalui bermain, anak usia 
dini akan berinteraksi dengan teman sebaya dan salah satu cara untuk memahami dan mengenali lingkungan sekitar anak (Hayati, 2019).

Kenyataan yang terjadi di Pos PAUD Ar-Rayyan kemampuan motorik halus belum optimal yang dibuktikan dengan anak belum mampu memegang pensil dengan benar dan belum sempurna dalam membuat garis lengkung, seharusnya anak usia 3-4 tahun sudah mampu membuat garis lurus dan menumpuk delapan buah kubus (Rivanica, 2016). Selain itu pembelajaran yang dilakukan untuk meningkatkan motorik halus anak masih monoton yaitu hanya dilakukan dengan kegiatan menggambar dan mewarnasi dengan pensil warna dan krayon. Hal ini mengakibatkan anak menjadi bosan dan pembelajaran kurang menarik. Upaya untuk menanggulangi rasa bosan anak, guru perlu memberikan kegiatan lain yang menarik agar anak bersemangat dalam mengikuti kegiatan pembelajaran.

Hal yang luput dari perhatian orang yaitu meningkatkan kemampuan motorik anak dengan kegiatan cooking class berbasis kearifan lokal yaitu kegiatan cooking class dengan memanfaatkan bahan baku makanan yang ada di lingkungan sekitar anak. Cooking class dipilih sebagai pembelajaran yang menyenangkan dikarenakan dengan kegiatan cooking class ini menarik bagi anak. Hal ini dikarenakan kegiatan ini menuntut keaktifan anak dalam memanfaatkan panas pada bahan makanan untuk membuat bahan mentah menjadi makanan yang dapat dimakan dan memiliki rasa lebih enak yang mudah dicerna dan membunuh kuman-kuman yang terdapat didalamnya sehingga dapat memberikan manfaat bagi tubuh manusia (Sihite, 2000). Permainan digunakan dalam proses pembelajaran mampu membantu tercapainya tujuan pembelajaran, karena dalam permainan siswa merasa senang, nyaman, tidak bosan sehingga mampu mengikuti proses pembelajaran dengan baik. Permainan yang dikemas dengan cooking class berbasis kearifan lokal ini dikembangkan dalam proses pembelajaran terbukti dengan beberapa penelitian dengan tujuan menciptakan media yang inovatif, mudah dipahami, berdasarkan bahan makanan yang ada dilingkungan setempat serta berpengaruh dalam perkembangan kemampuan motorik.

Kegiatan cooking class yang diimplementasikan dalam kegiatan pembelajaran diharapkan dapat meningkatkan kemampuan motorik halus anak. Hasil penelitian menunjukkan cooking class yang diimplementasika mampu meningkatkan kognitif anak yaitu anak akan mengetahui lebih banyak bahan-bahan makanan yang dapat dimasak, selain itu juga meningkatkan pengetahuan anak tentang makanan sehat dan bergizi (Kebonsari \& Cimahi, 2017). Selain itu, cooking class juga dapat mendukung guru dalam melakukan inovasi pembelajaran (Nugraha S., Sendra, \& Eka Mahadewi, 2015). Pembelajaran cooking class dengan menerapkan pembelajaran kontekstual juga mampu meningkatkan motorik anak (Juniyanasari, 2015). Pembelajaran yang mendasarkan pada kearifan lokal mampu menunjukkan kekhasan dari suatu daerah baik makanan maupun adat istiadat (Ghufronudin, Zuber, \& Demartoto, 2017). Dengan demikian peneliti meningkatkan kemampuan motorik anak dengan mengimplementasikan kegiatan cooking class berbasis kearifan lokal.

\section{METODOLOGI}

Penelitian ini merupakan penelitian tindakan kelas (classroom action research) dengan tujuan meningkatkan kualitas pembelajaran di kelas (Arikunto, 1992). Peneliti berkolaborasi dengan guru kelas yang bersangkutan dengan cara melaksanankan, dan merefleksikan tindakan secara kolaboratif dan partisipatif yang bertujuan untuk memperbaiki atau meningkatkan suatu proses pembelajaran dikelasnya melalui tindakan tertentu dalam suatu siklus (Kunandar, 2010). Penelitian bertujuan menguji efektifitas pembelajaran cooking class untuk meningkatkan motorik halus anak, serta faktor-faktor yang mempengaruhi perkembangan motorik halus anak usia dini.

Penelitian ini dilakukan di Pos PAUD Ar-Rayyan yang merupakan daerah miskin tepatnya kecamatan Tempuran Kabupaten Magelang berjumlah 15 siswa dengan usia 3-4 tahun. Waktu penelitian dilaksanakan pada bulan Februari s.d April 2019. Mulyasa (2003) 
berpendapat pembelajaran diketahui berhasil dan berkualitas apabila seluruhnya atau setidaknya sebagian besar $75 \%$ peserta didik terlihat secara aktif baik secara fisik, mental maupun sosial dalam proses pembelajaran. Sehingga dalam penelitian ini kemampuan motorik halus anak dikatakan berhasil ketika kemampuan sudah mencapai $75 \%$. Pengumpulan data dengan menggunakan observasi dan wawancara. Data-data yang diperoleh dianalisis menggunakan analisis kuantitatif deskriptif. Analisis tersebut digambarkan dengan hasil perhitungan berupa angka dan dari hasil tersebut akan dijelaskan secara deskriptif. Adapun prosedur penelitian dapat diamati dalam gambar di bawah ini:

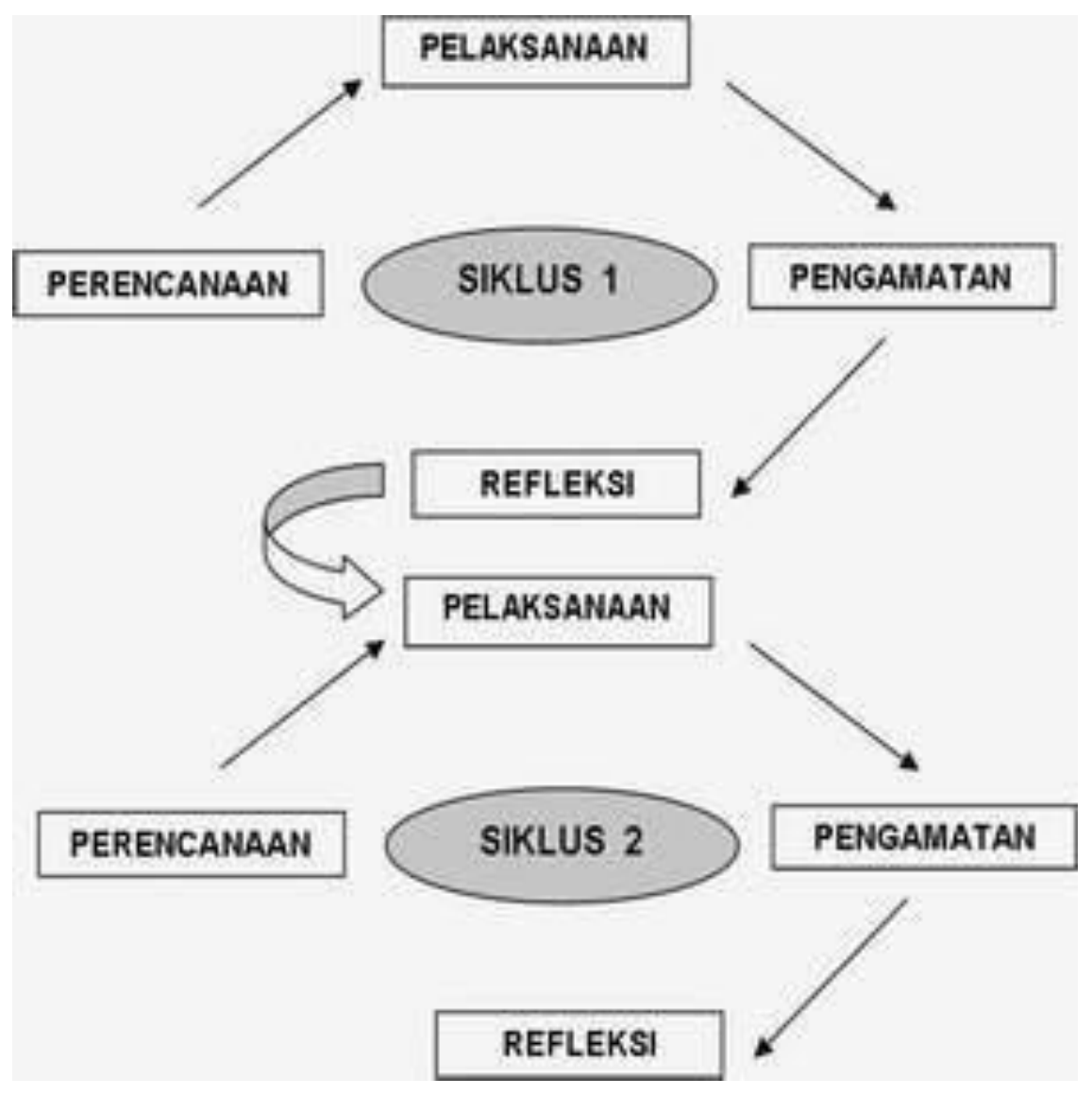

Gambar 1 Model Penelitian Tindakan dari Kurt Lewin

\section{HASIL DAN PEMBAHASAN}

\section{Data Awal Kemampuan Motorik Halus Anak}

Penelitian yang dilaksanakan oleh peneliti sesuai dengan rencana tahapan kegiatan yang telah ditetapkan oleh peneliti sebelumnya. Penelitian ini diawali dengan kegiatan observasi kemampuan motorik halus anak di Pos PAUD Ar-Rayyan Desa Riginanom Tempuran Magelang.

Berdasarkan hasil observasi yang dilakukan peneliti, ada beberapa anak dalam satu kelas yang kemampuan motorik halus perlu untuk ditingkatkan. Kemampuan motorik halus anak usia 3-4 tahun meliputi meronce benda yang cukup besar, melakukan eksplorasi dengan berbagai media dan kegiatan, dan menggunting dengan mengikuti pola. Kemampuan meronce yang dimiliki anak masih perlu distimulasi lagi, hal ini dikarenakan roncean yang dihasilkan anak belum sesuai dengan pola diminta oleh guru, selama ini media yang dimanfaatkan oleh guru untuk kegiatan meronce dengan manik-manik yang ukuran lubangnya sangat kecil sehingga anak kesulitan untuk memasukkan manik-manik ke dalam senar yang sudah diseduakan oleh sekolah. Kemampuan motorik halus kegiatan menggunting sesuai garis juga masih perlu distimulasi. Hal ini dikarenanan otot otot tangan 
masih sangat kaku sehingga ketika anak memegang gunting masih belum pas posisi tangannya dan hasil guntingannya belum rapi serta belum sesuai dengan pola yang ada. Kemampuan awal motoik halus anak dapat dilihat pada tabel berikut ini:

Tabel 1 Data Kemampuan Awal Kemampuan Motorik Halus

\begin{tabular}{|c|c|c|c|}
\hline No & Responden & Skor & Prosentase $(\%)$ \\
\hline 1 & AR & 9 & 60 \\
\hline 2 & ANG & 9 & 60 \\
\hline 3 & $\mathrm{AL}$ & 8 & 53,33 \\
\hline 4 & IW & 6 & 40 \\
\hline 5 & SN & 7 & 46,67 \\
\hline 6 & RS & 9 & 60 \\
\hline 7 & BT & 5 & 33,33 \\
\hline 8 & RK & 9 & 60 \\
\hline 9 & DL & 7 & 46,67 \\
\hline 10 & $\mathrm{AR}$ & 8 & 53,33 \\
\hline 11 & $\mathrm{AL}$ & 8 & 53,33 \\
\hline 12 & RSM & 7 & 46,67 \\
\hline 13 & ND & 8 & 53,33 \\
\hline 14 & ALW & 9 & 60 \\
\hline \multirow{2}{*}{15} & FIA & 7 & 46,67 \\
\hline & Rata-ra & & 51,56 \\
\hline
\end{tabular}

Berdasarkan tabel di atas menunjukkan bahwa kemampuan motorik halus rata-rata kelas mencapai 51,56 \%. Kemampuan masing-masing anak dapat dilihat pada grafik di bawah ini:

\section{Kemampuan Motorik Halus}

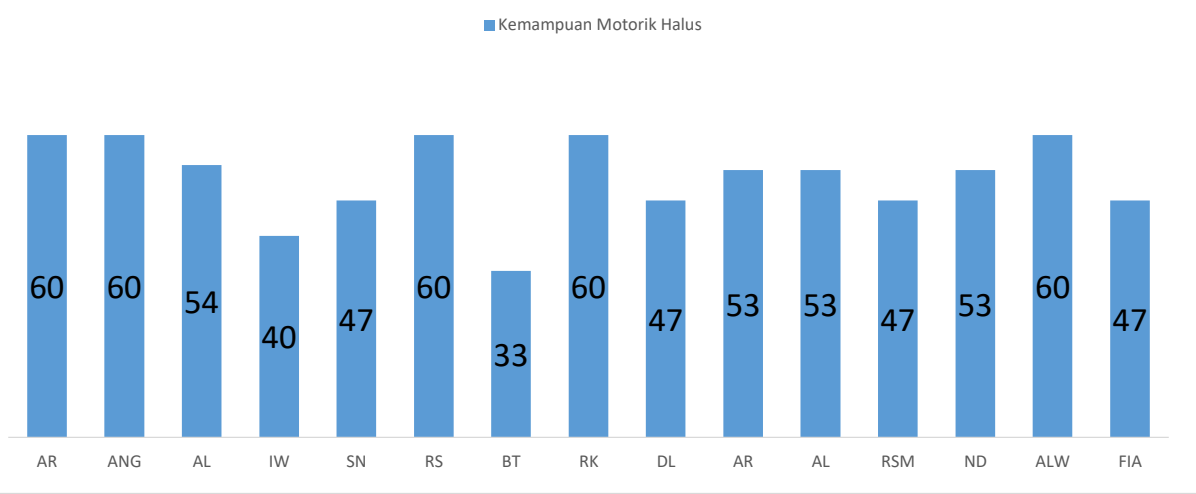

Gambar 2 Data Awal Kemampuan Motorik Halus Anak

\section{Kemampuan Motorik Halus Anak Setelah siklus I dan Siklus II}

Berdasarkan pengamatan yang dilakukan oleh peneliti melalui kegiatan memasak (cooking class) untuk meningkatkan kemampuan anak dalam motorik halus sudah menunjukan peningkatanya. Kegiatan cooking class yang dilaksanakan sebanyak 2 siklus dan satu siklus terdiri dari 6 pertemuan meliputi kegiatan membuat sate buah, membuat dan menghias nasi kluban, membuat dan menghias nasi kuning, menghias roti tawar, membuat minum susu, serta membuat minuman sirup dari bahan makanan yang ada di lingkungan sekitar sekolah. Peningkatan kemampuan motorik halus tersebut dapat dilihat dari adanya peningkatan kemampuan anak dalam keterampilan motorik halus pada pertemuan dan pengukuran yang dilakukan pada saat pengukuran awal kemampuan motorik halus sebelum siklus dan data setelah dilakukan tindakan pada siklus I dan siklus II. 
Peningkatan yang dapat terlihat pada anak usia 3-4 tahun ini terkait kemampuan motorik halusnya yaitu pada kegiatan meronce yang semula dengan manik-manik anak kesulitan untuk memasukkan lubang dan mengikuti pola yang telah ditentukan oleh guru, setelah dilakukan tindakan kegiatan membuat sate buah dengan pola buah yang sudah ditentukan guru dan disiapkan oleh guru serta kegiatan meronce bahan alam yang ada disekitar lingkungan sekolah, maka anak menjadi mampu utuk melakukan kegiatan meronce sendiri tanpa bantuan guru dan mampu mengurutkan roncean sesuai pola yang sudah ditentukan oleh guru.

Selain itu melalui tindakan cooking class dengan kegiatan menghias roti (mengoleskan mentega, menaburkan meses dan kelengkapan lainnya), menyiapkan dan menghias nasi kluban, nasi kuning, serta membuat minuman sendiri tanpa bantuan guru menjadikan otot-otot tangan anak menjadi lemas dan memudahkan untuk memegang dan melakukan kegiatan menggunting sesuai pola yang ada serta menempelkan hasil guntingan sesuai pola yang benar.

Pembelajaran melalui kegiatan memasak (cooking class) untuk meningkatkan kemampuan motorik halus anak usia 3-4 tahun Pos PAUD Ar-Rayyan Kecamatan Tempuran Kabupaten Magelang telah menunjukan adanya peningkatan yang memuaskan, baik dari suasana kelas yaitu saat terjadi pembelajaran anak terlihat antusias karena guru belum pernah merencanakan kegiatan cooking class di dalam kelas dan dalam kegiatan pembelajaran memanfaatkan bahan alam yang ada dilingkungan sekitar. Selain itu juga terlihat peningkatan kemampuan motorik halus masing-masing anak. Adapun kemampuan motorik halus anak pada kemampuan awal, siklus I dan siklus II dapat dilihat dalam tabel di bawah ini.

Tabel 2 Data Kemampuan Motorik Halus Setelah Tindakan Siklus I dan Siklus II

\begin{tabular}{|c|c|c|c|c|c|c|c|}
\hline \multirow{3}{*}{ No } & \multirow{3}{*}{ Resp } & \multicolumn{3}{|c|}{ Skor } & \multicolumn{3}{|c|}{ Prosentase } \\
\hline & & & Siklus & Siklus & & Siklus & Siklus \\
\hline & & Awal & I & II & Awal & I & II \\
\hline 1 & AR & 9 & 11 & 14 & 60 & 73.33 & 93.33 \\
\hline 2 & ANG & 9 & 12 & 14 & 60 & 80 & 93.33 \\
\hline 3 & $\mathrm{AL}$ & 8 & 10 & 11 & 53.33 & 66.67 & 73.33 \\
\hline 4 & IW & 6 & 6 & 6 & 40 & 40 & 40 \\
\hline 5 & $\mathrm{SN}$ & 7 & 11 & 13 & 46.67 & 73.33 & 86.67 \\
\hline 6 & RS & 9 & 12 & 14 & 60 & 80 & 93.33 \\
\hline 7 & BT & 5 & 7 & 10 & 33.33 & 46.67 & 66.67 \\
\hline 8 & RK & 9 & 10 & 11 & 60 & 66.67 & 73.33 \\
\hline 9 & DL & 7 & 8 & 12 & 46.67 & 53.33 & 80 \\
\hline 10 & $\mathrm{AR}$ & 8 & 10 & 13 & 53.33 & 66.67 & 86.67 \\
\hline 11 & $\mathrm{AL}$ & 8 & 9 & 14 & 53.33 & 60 & 93.33 \\
\hline 12 & RSM & 7 & 8 & 12 & 46.67 & 53.33 & 80 \\
\hline 13 & ND & 8 & 10 & 13 & 53.33 & 66.67 & 86.67 \\
\hline 14 & ALW & 9 & 10 & 13 & 60 & 66.67 & 86.67 \\
\hline 15 & FIA & 7 & 7 & 8 & 46.67 & 46.67 & 53,33 \\
\hline \multicolumn{2}{|c|}{ Rata-rata kelas } & 7.73 & 9.4 & 11.8 & 51.56 & 62.67 & 79,11 \\
\hline
\end{tabular}

Berdasarkan tabel di atas dapat diketahui bahwa kemampuan motorik halus anak meningkat dari data awal awal 51,56 \%, siklus I meningkat menjadi 62,67 \% dan siklus II menjadi $79,11 \%$. Peningkatan kemampuan motorik halus anak dapat terlihat jelas pada grafik di bawah ini: 


\section{Chart Title}

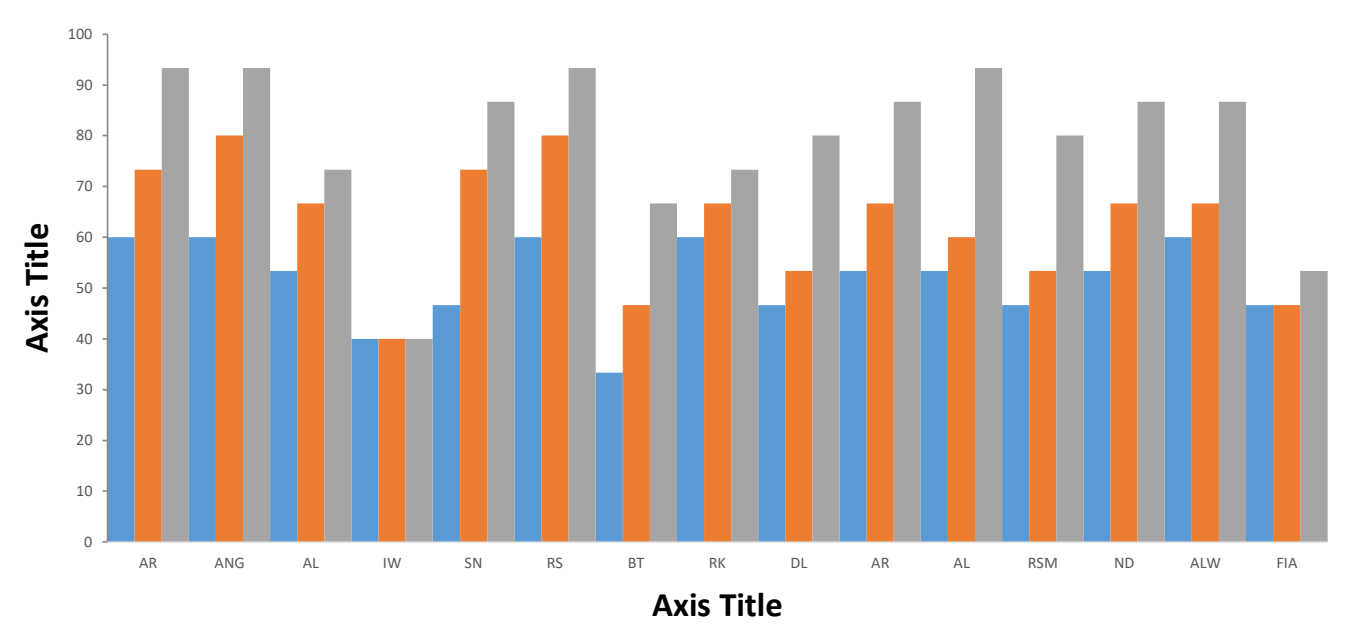

\section{Gambar 3 Data Kemampuan Motorik Halus Setelah Tindakan Siklus I dan Siklus II}

\section{Hasil Refleksi Siklus I dan Siklus II}

Kegiatan untuk meningkatkan kemampuan motorik halus anak melalui kegiatan memasak (cooking class) membuat kegiatan pembelajaran menjadi lebih menyenangkan, selain itu juga menarik minat anak untuk belajar. Proses pembelajaran cooking class mampu membantu melemaskan otot-otot tangan anak sehingga mampu menggunakan tangan sesuai kebutuhan. Kemampuan awal yang dimiliki oleh peserta didik $51,56 \%$, setelah dilakukan tindakan pada siklus I meningkat menjadi $62,67 \%$. Hasil yang didapatkan pada siklus I masih harus ditingkatkan karena belum memenuhi target yang diharapkan yaitu minimal $75 \%$. Oleh karena itu dilanjutkan dengan tindakan siklus II dan hasil yang diperoleh lebih kondusif, dengan cara mengelompokan anak kedalam beberapa kelompok. Sebelum kegiatan dimulai anak diberi penjelasan tentang alat dan bahan yang akan digunakan. Berdasarkan hasil diskusi dengan kolaborator telah diperoleh banyak peningkatan dalam kegiatan penelitian yang dilakukan pada siklus II.

Kemampuan motorik halus pada siklus II ini sebagian besar anak sudah berkembang dengan baik, anak sudah mampu meronce sesuai pola dengan baik, anak mampu melakukan eksplorasi dengan berbagai media dan kegiatan, serta anak sudah mampu melakukan koordinasi antara mata dan tangan yaitu menggunting sesuai pola. Kemampuan yang dimiliki meningkat menjadi 79,11 \%. Berdasarkan hasil penelitian yang diperoleh pada siklus II, dapat disimpulkan bahwa kegiatan pembelajaran untuk meningkatkan kemampuan motorik halus telah berhasil, maka peneliti dan kolaborator menghentikan penelitian tindakan pada siklus II.

\section{Pembahasan}

Berdasarkan data hasil penelitian peningkatan kemampuan motorik halus anak melalui kegiatan cooking class berbasis kearifan lokal telah diperoleh data awal kemampuan motoric halus 51,56 \%, siklus I meningkat menjadi $62,67 \%$ dan siklus II menjadi $79,11 \%$ dibuktikan dengan anak mampu melakukan kegiatan meronce dengan baik sesuai dengan pola yang ditentukan oleh guru, anak mampu menggunting sesuai pola yang ada kemudian menempelkan hasil guntingan sesuai perintah, serta anak mampu memegang pensil dengan baik dan mencontoh sesuai perintah guru. Hal ini dikarenakan cooking class juga dapat mendukung guru dalam melakukan inovasi pembelajaran (Nugraha S. et al., 2015). 
Data penelitian menunjukkan peningkatan kemampuan kemampuan membaca permulaan pada setiap anak didik. Kenyataan yang terjadi ketika kegiatan penelitian berlangsung data yang diperoleh peneliti kemampuan motoric halus pada responden IW tidak mengalami peningkatan yaitu berada pada data $40 \%$ baik dari data awal, siklus I dan siklus II tidak mengalami peningkatan. Keadaan ini dapat dilihat dalam grafik di bawah ini:

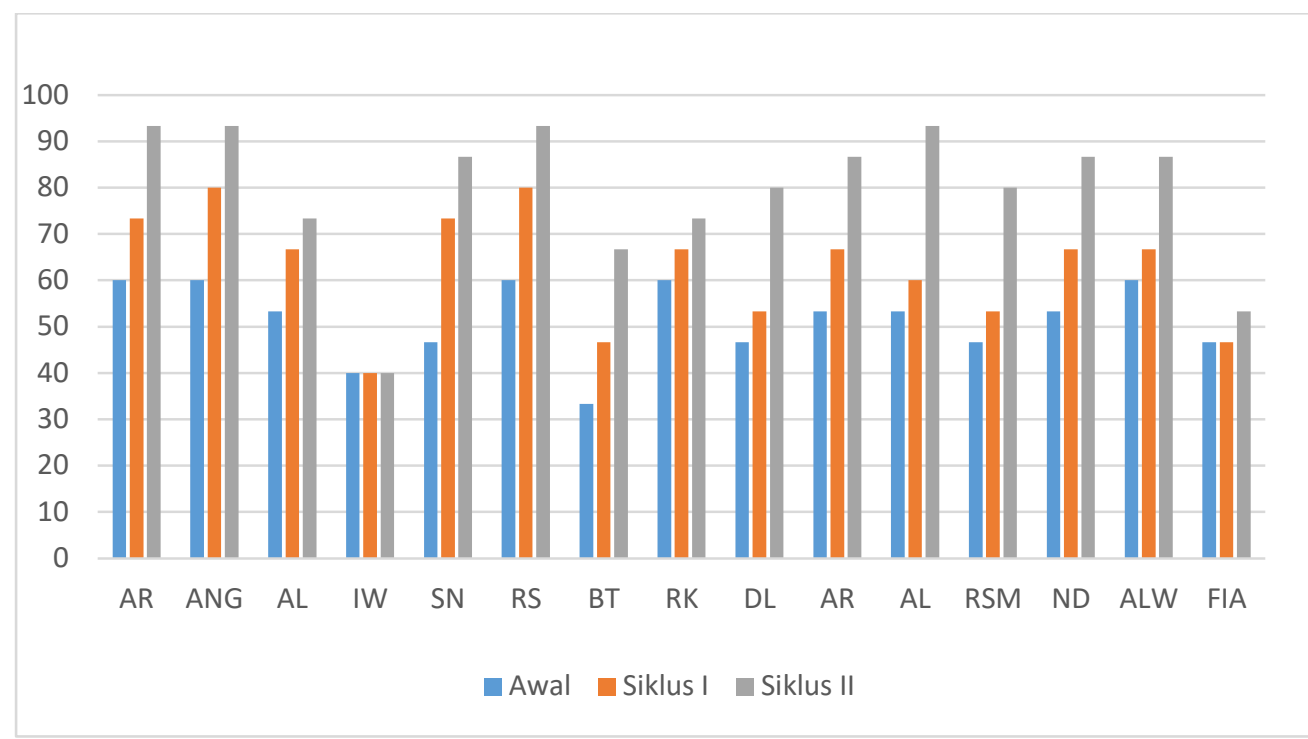

\section{Gambar 4 Data Kemampuan Motorik Halus Setelah Tindakan Siklus I dan Siklus II}

Setelah dilakukan pengamatan selama berlangsungnya penelitian, IW tidak mengalami peningkatan kemampuan motorik halus yang disebabkan karena beberapa hal yaitu diantaranya anak masih harus ditunggui oleh orang tua selama proses pembelajaran berlangsung, IW dalam kegiatan cooking class belum ikut aktif dalam kegiatan tersebut, sehingga ketika anak diminta untuk mempraktekkan suatu kegiatan anak hanya berdiam diri dan tidak mau mengikuti perintah guru.

Kekhawatiran orang tua anak tidak mendapatkan hasil yang baik ikut serta dalam penyebab kemampuan motorik halus tidak meningkat yang dibuktikan dengan ketika kegiatan penugasan berlangsung, orang tua masuk kelas dan ikut serta membantu pekerjaan anak supaya mendapatkan hasil yang bagus. Kesadaran orang tua pentingnya suatu proses pembelajaran masih kurang sehingga orang tua masih berorientasi pada hasil sehingga orang tua ikut serta dalam pengerjaan penugasan yang diberikan ke anak supaya mendapatkan hasil yang maksimal.

Kedekatan emosional antara guru dan anak didik merupakan hal yang sangat penting, anak selalu memanggil orang tua ketika penugasan berlangsung menunjukkan bahwa belum ada kedekatan emosional antara pendidik dan anak didik. Dengan demikian dapat disimpulkan bahwa beberapa factor yang mempengaruhi peningkatan kemampuan motorik halus anak yaitu diantanya: stimulus yang diberikan oleh orang tua dan pendidik, kurangnya kemandirian anak dalam kegiatan pembelajaran, kurangnya kesadaran orang tua akan pentingnya proses daripada hasil, kurangnya kepercayaan orang tua terhadap kemampuan anak, dan kedekatan emosional antara pendidik dan peserta didik.

\section{SIMPULAN}

Pembelajaran cooking class berbasis kerifan lokal dalam hal ini bahan-bahan yang dapat ditemui disekitar sekolah mampu meningkatkan kemampuan motorik halus anak usia 3-4 tahun yang dibuktikan terjadi peningkatan kemampuan motorik halus dari data awal hingga siklus II. Faktor-faktor yang mempengaruhi perkembangan motorik halus anak usia 3-4 tahun yaitu diantaranya stimulus yang diberikan oleh orang tua dan pendidik, 
kemandirian anak dalam kegiatan pembelajaran, kesadaran orang tua akan pentingnya proses daripada hasil, kepercayaan orang tua terhadap kemampuan anak, dan kedekatan emosional antara pendidik dan peserta didik.

\section{UCAPAN TERIMAKASIH}

Ucapan terimakasih dipersembahkan untuk Lembaga Penelitian Pengembangan dan Pengabdian kepada Masyarakat (LP3M) Universitas Muhammadiyah magelang yang telah mendanai penelitian ini melalui SKIM Penelitian Revitalisasi Visi Institusi (PRVI).

\section{DAFTAR PUSTAKA}

Arikunto, S. (1992). Prosedur Penelitian: Suatu Pendekatan Praktek. Cetakan ketujuh. Jakarta: Rineka Cipta.

Cllaudia, E. S., Wdiastuti, A. A., \& Kurniawan, M. (2018). Origami Game for Improving Fine Motor Skills for Children 4-5 Years Old in Gang Buaya Village in Salatiga. Jurnal Obsesi : Jurnal Pendidikan Anak Usia Dini, 2(2), 143. https://doi.org/10.31004/obsesi.v2i2.97

Ghufronudin, Zuber, A., \& Demartoto, A. (2017). Representasi-Pendidikan-Karakter Berbasis Kearifan Lokal melalui pembelajaran membatik. Jurnal Aanalsisi Sosiologi, 6(2), 30-37.

Hayati, M. \& S. P. (2019). Perencanaan Pembelajaran Pendidikan Anak Usia Dini. Depok: PT Raja Grafindo Persada.

Indraswari, L. (2014). Peningkatan Perkembangan Motorik Halus Anak Usia Dini Melalaui Kegiatan Mozaik Di Taman Kanak-Kanak Pembina Agam. Pesona PAUD, 1(1), 1-13.

Juniyanasari, L. P. (2015). Penerapan Pembelajaran Kontekstual melalui Cooking Class untuk Meningkatkan Keterampilan Motorik Halus pada Anak. E-Journal Universitas Pendidikan Ganesha Jurusan Pendidikan Anak Usia Dini, 3(1).

Kebonsari, S. D. N., \& Cimahi, I. K. (2017). Peningkatan Pengetahuan tentang Makanan Sehat melalui Kegiatan Bermain Cooking Class. Jurnal Care (Children Advisory Research and Education), 4(3), 1-17.

Kunandar. (2010). Langkah mudah penelitian tindakan kelas sebagai pengembangan profesi guru. $55-76$.

Kusumaningtyas, K., \& Wayanti, S. (2016). Faktor Pendapatan Dan Pendidikan Keluarga Terhadap Perkembangan Motorik Halus Anak Usia 3-4 Tahun. Jurnal Penelitian Suara Forikes, VII(2011), 52-59.

Ningrum, M. T. (2015). Meningkatkan Kemampuan Motorik Halus Anak melalui Kegiatan Menganyam di Kelompok B TK ABA II Pantoloan.

Nugraha S., M. R., Sendra, I. M., \& Eka Mahadewi, N. P. (2015). Cooking Class Sebagai Paket Wisata di Restoran Laka Leke Ubud Bali. Jurnal IPTA, 3(1), 29. https:// doi.org/10.24843/ipta.2015.v03.i01.p06

Nurani, Y. (2009). Konsep Dasar Pendidikan Anak Usia Dini. Jakarta: PT Indeks.

Pendidikan, K., \& Kebudayaan, D. A. N. (n.d.). Kemendikbud RI Tahun 2015 tentang Rencana Strategis Kementrian Pendidikan Dan Kebudayaan 2015 - 2019. 51(2), 1-205. https:/ / doi.org/10.1017/CBO9781107415324.004

Rakimahwati, R., Lestari, N. A., \& Hartati, S. (2018). Pengaruh Kirigami Terhadap Kemampuan Motorik Halus Anak di Taman Kanak-Kanak. Jurnal Obsesi : Jurnal Pendidikan Anak Usia Dini, 2(1), 98. https:/ / doi.org/10.31004/obsesi.v2i1.13

Rivanica, R. \& M. O. (2016). Buku Ajar Deteksi Dini Tumbuh Kembang dan Pemeriksaan Bayi Baru Lahir. Jakarta: Salemba Medika.

Romlah, R. (2017). Pengaruh Motorik Halus dan Motorik Kasar terhadap Perkembangan Kreatifitas Anak Usia Dini. Tadris: Jurnal Keguruan Dan Ilmu Tarbiyah, 2(2), 131. https://doi.org/10.24042/tadris.v2i2.2314

Santi, D. (2009). Pendidikan Anak usia Dini. Jakarta: Indeks. 